\title{
Practicing the International Theme of America versus Europe through Depicting Their Cultures, Characters and Settings, in The Portrait of a Lady by Henry James
}

\author{
Davood Mohammadi Moghadam ${ }^{a}$, Wan Roselezam Wan Yahya ${ }^{b}$ \\ Faculty of Modern Languages and Communication, University Putra Malaysia, \\ Kuala Lumpur, Malaysia \\ a,b E-mail address: ecodavood_nature@yahoo.com, roselezam@gmail.com
}

\begin{abstract}
Henry James is the most prominent American novelist who practices the international novels which deals with America and Europe. Among the subjects and the themes which James wrote about, his international theme is the most recurrent theme in his work, in other words we can say that James's international theme is the main an the most important subjects of his literary career. James's literary career is divided into three periods and the international theme is the main subject of the first and the third period, so its importance is obvious. This international theme is called in other words the issue of 'America versus Europe' through which James tried to show the contrasts which he believed to exist between America and Europe. In the days of Henry James it was as a defined duty for American writers to represent the contrast of America and Europe, because they were exhausted to be looked as a second-hand European. While in those days Americans looked themselves as inferior to European, so American writers defined to write about their contrast with Europe to be separated from Europe and that illusion. The Portrait of a Lady is James' most well-known masterpiece; this novel is again an international novel in which James practiced the international theme with a high proficiency because all parts of this novel, including its characters, settings and events are used skillfully like a chain to show the contrast between America and Europe.
\end{abstract}

Keywords: Henry James; International theme; America versus Europe; Neutrali

\section{INTRODUCTION}

Although The Portrait of a Lady belongs to the first period of James's literary career when he was yet immature in writing, it is the most well-known masterpieces of him, as Clarke confirms in his book, "The Portrait of a Lady (1881) is the first of the list of 'great' novels produced by Henry James" (191). All the parts of this novel are like a chain which helps James professionally practice his international theme of America versus Europe which is the most important subject in Henry James' literary career:

Among the central motifs that can be traced throughout Henry James's career as a writer is his concern with the social and moral differences between the New World and Europe (mainly represented by England, Italy 
and France), which he called the "Americano-European legend" and is otherwise frequently referred to as the "international theme". (Munch 2)

In this novel James practiced this international theme again through his common basic pattern of bringing an American girl into a European society. Through the adventure of this American girl who is the heroine of this novel James portrayed the contrasts between America and Europe, the contrast which he felt during his experience of living in both American and European society. Actually it was a responsibility and a duty for American writers of those days to define their country separated from Europe. In the days of James, Europe was looked superior than America, it was thought to be the place of high culture. Americans of those days had a dream of living in Europe because in their mind everything good and high was exited Europe, even if a writer wanted to be praised in his/her own country, America, he/she should first proved him/herself in America. American writers and artists were exhausted of being looked as a second-hand European; they had thought they culture to be a mixed one of other European culture. So they were exhausted of such a situation and wanted to be separated from Europe and have a pure American culture. So "the duty that was defined for the American writers of $19^{\text {th }}$ century [...] was to fight against the superiority of Europe over their country in those days" (Mohammadi Moghadam 91).

The Portrait of a Lady shows the international theme of 'America versus Europe' in the best way because James used all the parts of the story like the characters, cultures, settings and events for his purpose to show the contrast between America and Europe.

\section{DISCUSSION}

At the begging of the story there is a description of an afternoon tea which belongs to the English culture, during their afternoon tea, Mr. Touchett, his sick son, Ralph and Lord Warburton, an English lord who is a friend of the Touchett's family, are discussing about the American young lady (Isabel Archer) who is coming to live with them in the Gardencourt. About this afternoon tea, Richard Chase is his paper The Lesson of the master, writes:

On the broad, sloping lawn of the mansion James calls Gardencourt we discover people taking tea, and they are finding agreeable, not only because it tastes good but because drinking it is a mild ritual by which they show themselves to be a part of a way of life.... (1)

This way of life which they are trying to match themselves with, is a European way of life. Looking at the life of Daniel Touchett we can see one major issue that exists in this novel and in most of James's novels and that is the process of leaving America and its culture and coming to Europe in the search of civilization and a better life. We see that Daniel Touchett had left America and came to London to a European society and tried to match himself to the European way of life. And again in this novel the search for culture, civilization and better life is something which drives Isabel to leave America and travel to Europe. This is the realistic process of Americans travel to Europe in those days which James shows in his novels.

Like many American of those days and like James himself, Isabel Archer is going to find a better life, she decided to travel and live in Europe. So by leaving Albany in America and going to Gardencourt in London, Isabel is leaving America and its way of life and 
adopting herself to a European one. And it is through Isabel's decision for living in Europe that the international theme of America versus Europe is depicted in this novel.

The first way of showing the contrast between America and Europe in this novel, is the way which James used to show the houses in America and Europe, the houses in which Isabel lived. Actually the houses stands for countries, Albany the house where Isabel lived in America is standing for America and Gardencourt the house where Isabel lived in London is standing for England or for Europe.

The house in America in Albany in which Isabel lived had an important room which is named "the office" and it is in this room where at the beginning of the novel Isabel was sitting alone and reading a book, and it was in this room "the office" where Isabel visit her aunt Mrs. Lydia Touchett for the first time. The name of this room in Albany represents the condition of America; it shows America's "officiousness" as a result of industrialization, it represents America's official and democratic nature. In America there existed lecture halls and platforms but there was lack of royal residences and glorious palaces, there is no remarkable figure, so this environment cannot be match with Isabel's ideals for high culture. For Isabel in America there was no sign of high culture.

Completely in contrast of the house in Albany, the Gardencourt in London was glorious. The environment in America cannot be compare with the Gardencourt in England. The Gardencourt was great, beautiful and had an old history, it was match with what Isabel expected; it was like a dream which came true for her, as James explained Gardencourt:

Her uncle's house seemed a picture made real; no refinement of the agreement was lost upon Isabel; the rich perfection of Gardencourt at once revealed a world of gratified a need. The large, low rooms, with brown ceilings and dusky corners, the deep embrasures and ... the deep greenness outside that seemed always peeping in, the sense of well-ordered privacy in the center of a "property"... these things were to the taste of our young lady, whose taste played considerable parts in her emotions. (1917: 41)

The entrance of Isabel to the Gardencourt is the sample of her entrance into the European culture and European society, because this house stands for Europe, so by coming to Gardencourt and feeling its greatness and its beauty, Isabel think that she is approaching to her goal of reaching to a high culture and civilization. In contrast of the old and common house of Albany, the high beauty of the Gardencourt was the sign of the high culture of Europe for which Isabel had the desire of and could not feel and found in America. Through the houses James is representing that the Europe is the place of high culture and the place of aesthetic, while the America lacks such a high culture and is poor in aesthetic.

The other way through which James practiced his international theme in this novel is through depicting the contrasts between characters. This contrast is mostly obvious in James's way of describing the figure of three characters at the begging of the novel, the way that James used to described the Lord Warburton, Ralph and Daniel Touchett. This contrast is again referring to the aesthetic differences; James represents this contrast obviously through explaining the appearance of these three characters. Lord Warburton is an English character, Ralph and his father Daniel Touchett are Europeanized Americans but they still have American characteristic and appearance and have still what James called "American physiognomy". About the "American physiognomy" of Daniel Touchett, James described:

The old gentleman at the tea-table, who had come from America... had brought with him, at the top of his baggage, his American physiognomy; and had not only brought it with him, but has kept it in best order, so that, if 
necessary, he might have taken it back to his own country with perfect confidence. (10)

When James describe the appearance of Lord Warburton and Ralph Touchett, the contrast which James is going to show between the English character who is the Lord Warburton and the American ones who are Ralph and Daniel Touchett is presented obviously. Of Lord Warburton James described:

One of the remarkably well-made man of five and thirty, with a face as English as that of the old gentleman I have just sketched was something else; a noticeably handsome face, fresh-coloured, fair and frank, with firm, straight features, a lively grey eye and rich chestnut beard. This person had a certain fortunate, brilliant exceptional look a happy temperament fertilized by a high civilization which would have made any observer envy him at a venture. (10)

Lord Warburton and Ralph Touchett are both young characters but young Warburton who is English and a sample of Europe is described fresher and more attractive than the young Ralph who is American and a sample of America. In whose description James states:

His companion... was a person of quite a different pattern, who, although he might have excited grave curiosity, would not, like the other, have provoked you to wish yourself, almost blindly, in his place. Tall, lean, loosely and feebly put together, he had an ugly, sickly, witty, charming face, furnished, but by no means decorated, with a straggling moustache and whisker. $\mathrm{He}$ looked clever and ill (10)

Europe as is shown in the form of Lord Warburton is healthy in contrast to young America who in the form of Ralph is shown sick. Europe is as Lord Warburton, handsome and has refined features; it has the advantage of high culture and civilization. America as shown in the figure of Daniel Touchett was successful and had several achievements but as shown in the form of Ralph it is not well-ordered and nourished by a high culture.

This contrast shown between America and Europe and this way of describing America is not unusual and bizarre for the condition of America in comparison to Europe in those days of Henry James. Americans in those days looked enviously to the culture of Europe this reality is even states by James in his description of Lord Warburton; "which would have made almost any observer envy him at a venture" (10).

They counted themselves as an inferior to Europe; they see their culture as a copy of other cultures and as something taken from other countries like England, so they were completely dissatisfied with their condition and their culture. And it was because of this reality that most of the American writers in those days should first become popular in Europe if they want to be accepted in their own country. Europe in those days was as a desired place for Americans, they all wishes to be as civilized as Europeans. So many Americans in those days traveled to Europe in search of culture and a better life, like what Touchetts, Isabel, Osmond, Madame Merle and even James himself did.

To know whether they were satisfied or not with their decision for coming to Europe one can notice that in this novel we see that most of those characters that leave America and travel to Europe in search of a better life are not satisfied with their condition because they feel that they are neither a proper European nor a real American. There are examples in this 
novel which shows the dissatisfaction of such American characters in Europe, for example Daniel Touchett although is living for many years in Europe but preserve his "American physiognomy", his wife Lydia Touchett, although is living in Europe, her friends are some selected Americans not Europeans. Even Madame Merle shows this dissatisfaction more obvious when she declares that "If we are not good Americans we are certainly poor Europeans" (137).

The contrast between these American characters and the European ones is emphasized when we see all American characters in this novel feel that they lack roots, and have no place of their own and no culture to be satisfied. But in the other hand a European character like Lord Warburton is presented to be honored by a high culture. Christof Wegelin in his book states: "Warburton is not false simply because he is not rootless. The traditions which the other pretends to, he possesses securely, legitimately." (74)

The other thing that shows the contrast between America and Europe in The Portrait of a Lady is the contrast which exists between the American Ladies especially Isabel Archer and the European or Europeanized American ladies. There is some contrast between the ideals of American ladies especially the heroine Isabel Archer and European or Europeanized American ladies, the major thing which reveals this contrast is the liberty and independence of Americans, which Isabel tried to preserve in her as a part of her American characteristic. When Daniel Touchett saw Isabel for the first time and asked: "Dear me, who is that strange woman?" Lord Warburton replied: "Perhaps it is Mrs. Touchett's niece - the independent young lady," (James 16), even when Isabel is speaking to Caspar Goodwood she declared "I like my liberty too much" again to him she said "I can do what I choose, I belong quite to the independent class" (James 114).

The attempt of Isabel in preserving her independence and liberty shows itself more obviously when Mr. Goodwood wanted to marry her and proposes to her, but she believed that marrying with him would be an obstacle in her way to reach to a good life, and may took her independence so in Goodwood's proposal, she replied that:

I therefore am not bound to be timid and conventional....I try to judge things for myself; to judge wrong, I think, is more honorable than not to judge at all. I don't wish to be a mere sheep in the lock; I wish to choose my fate.... remember what I have told you about my love of liberty. (James 114-115)

This liberty and independence which is shown to be as a part of American lady in this novel does not exist in European or Europeanized ladies, in the case of Europeanized American ladies like Lydia Touchett we can say she tried to forgive her American independence and liberty because she wanted to live as an European lady, because European ladies are less independent than the American ones. For example Isabel Archer as feel more liberty wants to stay longer at night with men, for example with Lord Warburton, but her aunt Mrs. Lydia Touchett does not accept this behavior so she warned Isabel that Gardencourt is not Albany and "Young girls here don't sit alone with the gentlemen late at night" (James 49).

Another example of Isabel's independence which was her American characteristic is shown when she is talking with her Aunt Mrs. Touchett, her aunt informed her that she is going to warn Isabel each time when Isabel is doing the behavior which is not accepted in Europe, so Isabel eagerly accept that "I always want to know the things one shouldn't do" in Europe, then her aunt asked "So as to do them?" but Isabel answered "so as to choose" (James 49), here Isabel's response to her aunt show that she is not going to forgive her American liberty and independence in the way that her aunt do, it show that Isabel as an 
American lady is not satisfied with European ladies way of life, she does not want to be bounded.

\title{
3. CONCLUSIONS
}

In the period in which Henry James lived, many Americans travelled to Europe. Two groups were the main of these Americans, the first one were the noble families who wanted to travel to Europe to preserve their nobility and the second ones were the Writers who saw Europe as the proper place for their literary talent.

One can declare that it was an ambition for most of the Americans to live in Europe in that time. Because as it was discussed, all the Americans look enviously to Europe and count themselves as inferior to European. They think that travel to Europe means to find a better life and reach to a high civilization. And when in their confrontation to Europe they saw the contrast between their country and Europe, most of them give their country up and tried to be Europeanized and forget all their American heritages whether they were better or worse than European characteristic, even they give up some good American behavior in order to be like European because they thought that all the European ideals are better than American ones.

Such a situation to give American way completely up and trying to fit to a European culture was not accepted by American writer and artists. They didn't want to have their culture as a mixed culture of different European ones, so as being exhausted of such a feeling of inferiority they defined their duty to write about 'America versus Europe' to be separated from Europe and to have a pure American culture. James also in The Portrait of a Lady tries to show the contrast between America and Europe in a realistic way. But he tries to remain neutral while he believed American should take benefits of European culture and learn from it, but not to give up their American way. All he expected from Americans is shown in the way that he portrayed Henrietta Stackpole in this novel. Christof Wegelin in his book The Image of Europe in Henry James believes:

\begin{abstract}
Above all, there is Henrietta Stackpole, the American lady reporter whom James uses as a means to dramatize, ironically but sympathetically nevertheless, certain phase of the American tradition of democratic criticism of Europe....she is aggressively suspicious of all that smacks of privilege and class, and most of all of American prostration before European standards. (Wegelin 1958: 64-65)
\end{abstract}

Henrietta does not give up her American conventions in order to fit herself to a European culture. She remains American but takes benefits from Europe. She learns there and gains knowledge for her purpose in her life, but never tries to act like a European, a mistake that was done by many Americans in this novel.

So Henrietta was James's message to Americans who travel to Europe, James wanted them to be like her in their confrontation to Europe. She did not give her country up and again she did not fight all European way of life but she tried to be an American and learn from Europe and from its acceptable characteristic. So she is portrayed the most successful American in Europe. 


\section{References}

[1] Chase Richard. "The Lesson of the Master." The American Novel and its Tradition. London: G. Bell, 1958: 117-22, 134-37.

[2] Clarke Graham. Henry James: Critical Assessments. Vol. 2. Mountfield near Robertsbridge: Helm Information, 1991. Print.

[3] James Henry. The Portrait of a Lady. Vol. XI. Harvard Classics Shelf of Fiction. New York: P.F. Collier \& Son, 1917; Bartleby.com, 2001; www.bartleby.com/311/.

[4] Davood Mohammadi Moghadam, Wan Roselezam Wan Yahya. A Study on the International Theme, as a Prominent Subject in the Works of Henry James. International Letters of Social and Humanistic Sciences 17(2) (2014) 85-94.

[5] Munch Marcus. The International Theme: The Conflict of National Types in the Tales of Henry James. Munich: Grin Verlag, 2007.

[6] Wegelin Christof. The Image of Europe in Henry James. Dallas: Southern Methodist University Press, 1958. 